\title{
2,4,6-TRIHYDROXYBENZOIC ACID IN THE TREATMENT OF RHEUMATIC FEVER
}

\author{
BY \\ E. B. D. HAMILTON AND E. G. L. BYWATERS \\ From the Rheumatism Research Unit (M.R.C.), Canadian Red Cross Memorial Hospital, Taplow
}

Clarke, Clarke, and Mosher (1958) have recently reported on the therapeutic action of 2,3,6- and 2,4,6-trihydroxybenzoic acid (THB) in twelve patients with rheumatic fever and eleven others. The latter compound, usually in a dosage of 1 to $1.33 \mathrm{~g}$. $/ 24 \mathrm{hrs}$, was believed to have a clinical antirheumatic potency six to eight times that of salicylic acid and no toxicity.

We have found it to have no anti-rheumatic potency in classical rheumatic fever, judged by pain and temperature response in three patientsreceiving doses varying from 1 to $8 \mathrm{~g} . / 24 \mathrm{hrs}$, whereas calcium aspirin (Disprin) in a dosage of about $4 \mathrm{~g} . / 24 \mathrm{hrs}$ was dramatically effective in the same three patients (Figure).

\section{REFERENCE}

Clarke, N. E., Clarke, C. N., and Mosher, R E. (1958). Amer. $J_{\bar{\partial}}^{\frac{\partial}{\sigma}}$ med. Sci., 235, 7 .

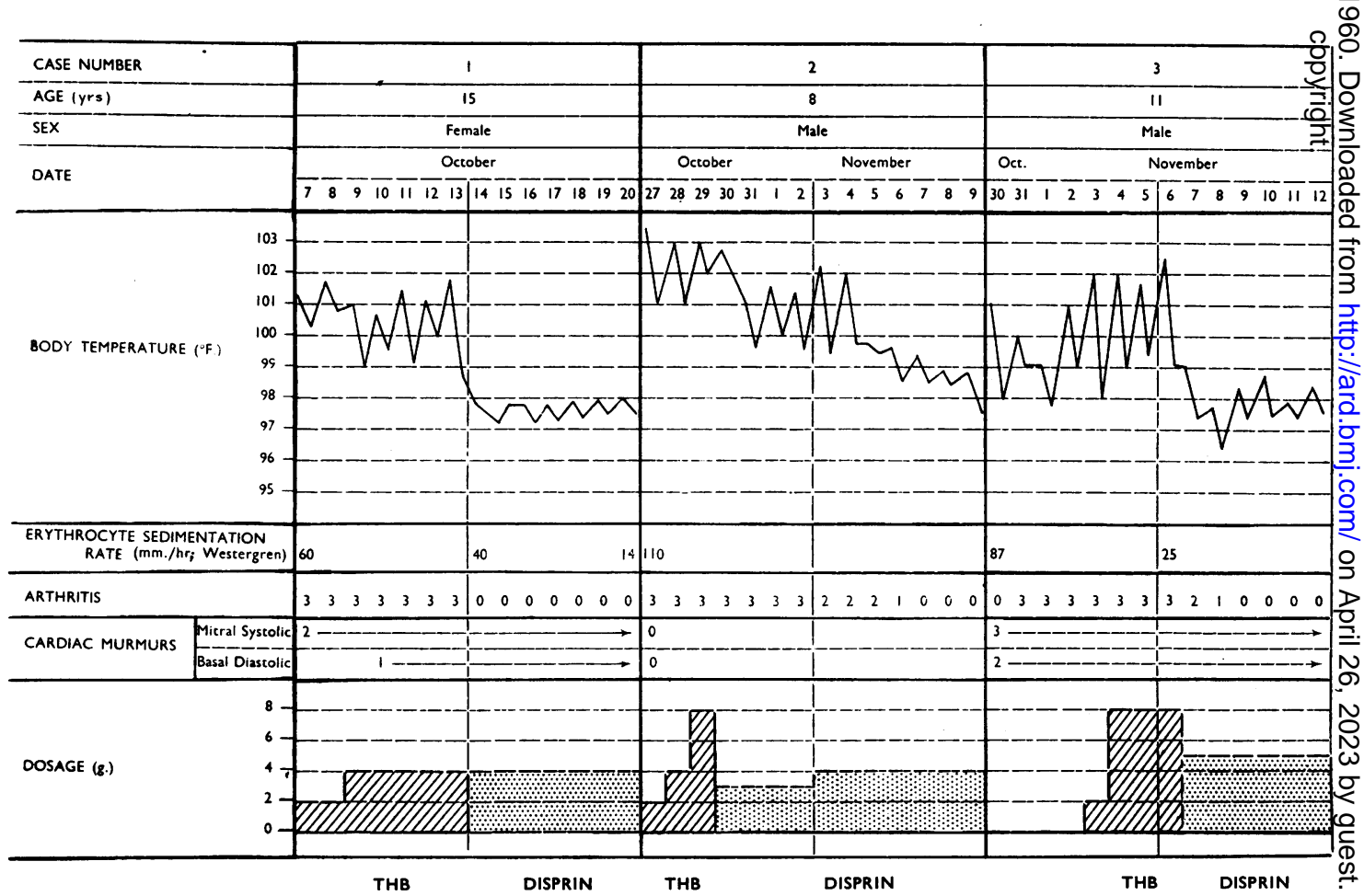

Figure.-Response of fever, erythrocyte sedimentation rate (Westergren), arthritis, and cardiac murmurs in three patients with rheumatic fever, treated with THB and Disprin. 


\section{APPENDIX}

\section{Case Reports}

Case 1, a girl aged 15 years, was admitted to hospital on October 7, 1958, having had a sore throat one month before admission which was followed 10 days later by the onset of flitting polyarthralgia. There had been transient substernal pain for 3 days.

Examination.-The body temperature was $101^{\circ} \mathrm{F}$. She had arthritis of the right wrist and left ankle, and an apical pansystolic murmur.

Therapy.-She was started on trihydroxybenzoic acid on October 8 , and received $2 \mathrm{~g}$. daily for 2 days and $4 \mathrm{~g}$. daily for 4 days. Throughout this time she ran a high fever with acutely inflamed joints. A soft basal diastolic murmur was first noted on October 10. Both cardiac murmurs were later confirmed by phonocardiogram and an electrocardiogram showed a prolonged PR interval. Because there was no response to THB she was given Disprin $4 \mathrm{~g}$. daily from October 13 . There was a prompt fall in body temperature, the joints were normal the following day, and the patient has since made uninterrupted progress.

Case 2, a boy aged 8 years, was admitted to hospital on October 27, 1958, having had a sore throat one month before admission and polyarthralgia for 4 days.

Examination.-The body temperature was $103^{\circ} \mathrm{F}$. He had acute arthritis of both wrists and ankles, but no cardiac murmurs.

Therapy.-He was started immediately on trihydroxybenzoic $2 \mathrm{~g}$. daily and this dose was doubled daily for

L'acide 2,4,6-trihydroxybenzoïque dans le traitement du rhumatisme articulaire aigu

RÉSUMÉ

L'acide 2,4,6-trihydroxybenzoïque (THB), à une dose de 1 à 8 grammes par jour, n'eut aucun effet antirhumatismal, jugé par la douleur et la température, sur trois cas de rhumatisme articulaire aigu classique, tandis que l'aspirine calcique (Disprin) administrée aux mêmes malades à la dose de 4 grammes par jour produisit un effet dramatique.
2 more days, but the treatment was changed to Disprin 3 g. daily on October 30 as he still had acute joint involvement and was running a high fever. The following day the arthritis in the ankles had subsided but there was still slight swelling of the wrists and the body temperature had fallen only slightly. He continued febrile and on November 1 complained of chest pain but no pericardial friction was heard. On November 3 a chest $x$ ray showed a large cardiac shadow suggestive of pericarditis but the electrocardiogram was normal. The dosage of Disprin was increased to $4 \mathrm{~g}$. daily, and he continued to improve. On November 8 and 9 the temperature did not rise above $99^{\circ} \mathrm{F}$., and the slight swelling of both wrists was less, and he could move them without pain.

Case 3, a boy aged 11 years, was admitted to hospital on October 30,1958 , with a 3-day history of polyarthralgia following a sore throat. This was a second attack of rheumatic fever.

Examination.-A basal diastolic murmur and mitral diastolic murmur were heard in addition to the preexisting mitral systolic murmur. He had erythema marginatum. The body temperature was $101^{\circ} \mathrm{F}$.

Therapy.-Despite being given trihydroxybenzoic acid 2 g. on November 3 and 8 g. daily from November 4 to 6 , he remained febrile with pain in the knees and elbows, and marked swelling of the left wrist. When Disprin $5.4 \mathrm{~g}$. daily was started on the evening of November 6 , the fever immediately fell to $95^{\circ} \mathrm{F}$. and the arthritis subsided.

\section{Acido 2,4,6-trihidroxibenzoico en el tratamiento del reumatismo poliarticular agudo}

\section{SUMARIO}

El ácido trihidroxibenzoico (THB), en dosis diaria de 1 a 8 gramos, no tuvo acción antirreumática alguna, juzgada por el dolor y la temperatura, en tres casos clásicos de reumatismo poliarticular agudo, mientras que la aspirina cálcica (Disprin) administrada a los mismos enfermos en dosis de 4 gramos diarios, produjo un efecto dramático. 